\title{
PREVALENCE AND RISK FACTORS FOR INTESTINAL PARASITIC INFECTIONS IN CHILDREN ATTENDING DAYCARE CENTERS IN ALFENAS, SOUTHERN MINAS GERAIS, BRAZIL
}

\author{
Amanda Aparecida Felizardo², Raquel Lopes Martins Souza ${ }^{1}$, Rosângela \\ Vieira Siqueira ${ }^{2}$ and Hermínia Yohko Kanamura ${ }^{1}$
}

\section{ABSTRACT}

\begin{abstract}
Intestinal parasitic infections are common among pre-school children in developing countries and they are often associated with gastrointestinal morbidity such as chronic diarrhea and malnutrition. Their circulation is mainly associated with lack of personal hygiene and environmental sanitation, as well as limited housing and food conditions. As the diagnosis of intestinal parasites is not a simple procedure, especially in population studies, due to difficulties encountered in strategies to obtain fecal samples, reliable prevalence data are scarce. Indeed, the epidemiological data on the prevalence of these parasites in different locations are important for the development of appropriate control measures. This study aimed to investigate the prevalence and risk factors associated with intestinal parasitic infection in children attending three public municipal daycare centers in Alfenas, MG. Three fecal samples from each child were collected on alternate days and processed by the spontaneous sedimentation technique and also through the commercially available centrifugal concentration technique, known as the TF-Test ${ }^{\circledR}$ (TFT). Information on the biological, social and physical environment, in which the children lived, were obtained through the application of a socio-epidemiological questionnaire to the parents or guardians and daycare staff. Giardia duodenalis was the parasite species most frequently detected among the children, with a positive rate of $27.8 \%$ (77/277). Entamoeba coli was detected in one of the daycare centers studied, with positivity rate of $43.7 \%,(7 / 16)$; and helminth infection in only two children. The present study showed that children of municipal daycare centers in Alfenas could be at risk of infection by intestinal parasites.
\end{abstract}

KEY WORDS: Intestinal parasites; prevalence; risk factors; daycare center.

\section{INTRODUCTION}

Parasitic infections by protozoa and helminthes are among the most frequently diagnosed diseases in humans. The damage that these parasites can cause in their hosts includes diarrhea, fever, anemia, malnutrition, and

\footnotetext{
1. Instituto de Ciências Biomédicas da Universidade Federal de Alfenas, Alfenas, MG, Brazil.

2. Faculdade de Ciências Farmacêuticas da Universidade Federal de Alfenas, Alfenas, MG, Brasil.

Corresponding author: Amanda Aparecida Felizardo. E-mail: amandafeliza@gmail.com
} 
malabsorption of nutrients, as well as hepatic impairment, respiratory and even neurological symptoms; the clinical manifestations are usually proportional to the parasitic load of the host. Although people in developing countries are the most affected by parasitic diseases, significant illnesses may also befound in developed countries (Fletcher et al., 2012; Pedraza et al., 2014).

Several factors may influence the high frequency of parasitic infections, either intestinal or systemic, but the most prevalent are deficient environmental sanitation, inadequate hygiene practices, and the precarious living conditions of millions of people around the world. In general, parasites are more common among individuals from low-income families, especially in rural areas, but also in urban areas with poor infrastructure. The oral route is the most common for the transmission of intestinal parasites, and contaminated water and food are the main transmission vehicles (Fletcher et al., 2012). Studies related to the frequency of intestinal parasitic infections, together with the analysis of social and environmental conditions of the studied population, can support the implementation of suitable prophylactic measures for controlling these diseases that still affect a significant number of individuals (Harhay et al., 2010; Osman et al., 2016).

This study aimed to diagnose intestinal parasites that affect children attending municipal daycare centers (DCCs) in Alfenas, MG. The responses to the questionnaires, from the children's parents, were analyzed for information on the biological, social, and physical environment in which the children were living.

\section{MATERIAL AND METHODS}

\section{Study area and target population}

The cross-sectional study was conducted in the municipality of Alfenas, located in the south/southwest region of the state of Minas Gerais (MG), Brazil, $343 \mathrm{~km}$ from Belo Horizonte, the capital of the state, with an estimated population of 78,712 inhabitants in July 2015 (IBGE, 2016). The study was carried out from March to November 2014, involving children attending three public DCCs, run by the local government and located in the urban area of Alfenas city. Among the 15 municipal daycare centers in Alfenas, the three involved in the present study were those which first showed interest in participating. The daycare centers, called CEMEI (Centro Municipal de Educação Infantil - Municipal Center for Early Childhood Education), were identified as follows: (1) CEMEI BF; (2) CEMEI BV, and (3) CEMEI JB (Figure 1). The distance of the three daycare centers $(1,2$, and 3$)$ from the city center was $3.1 \mathrm{~km}, 2.2 \mathrm{~km}$, and $2.0 \mathrm{~km}$, respectively, using the main church in Alfenas as the point of reference (Paróquia São José e Dores). 


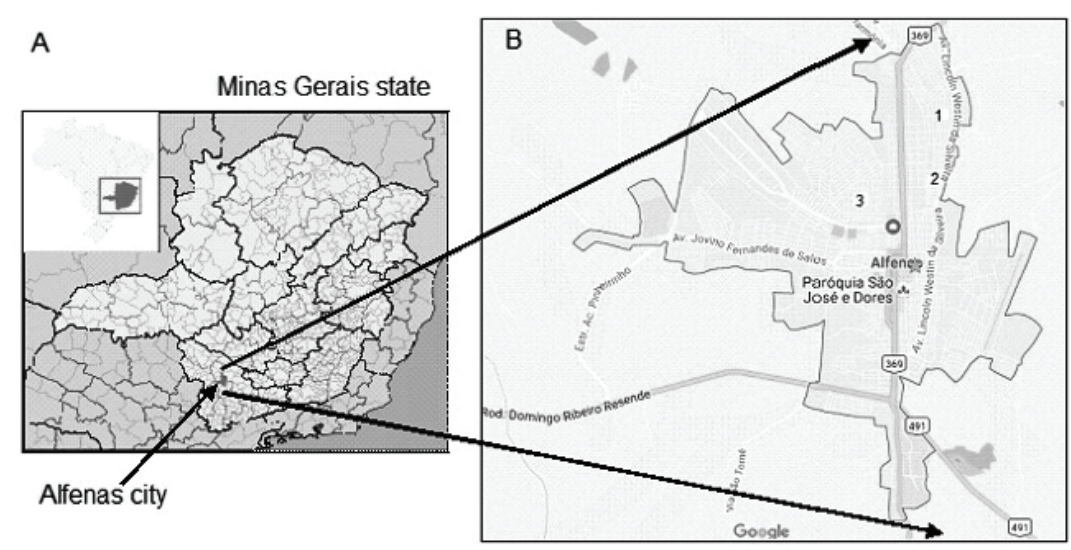

Figure 1. Localization of (A) Alfenas city in the southen region of Minas Gerais state and (B) the three daycare centers in the urban area of Alfenas: (1) CEMEI BF, (2) CEMEI BV, and (3) CEMEI JB.

source: <https://pt.wikipedia.org/wiki/Alfenas > and <http://mapasapp.com/ mapa/minas-gerais/alfenas-mg/>, with modifications by the authors.

\section{Fecal sample collection and parasitological examination}

After obtaining informed consent from parents or legal guardians, they were provided with an explanatory guide on how to proceed for the fecal sample collection. The samples were collected by parents or relatives at home or by the staff at the DCCs. No exclusion criteria were applied regarding participation in the study. A total of 621 children enrolled in the three studied daycare centers were invited to participate in the study, although only 277 effectively provided fecal samples. Three fecal samples from each child were collected on alternate days and placed in plastic tubes containing formaldehyde, as the preservative medium, then processed through the commercially available centrifugal concentration technique, known as the TF-Test ${ }^{\circledR}$ (TFT) (ImmunoAssay ${ }^{\circledR}$, Itupeva, Brazil), according to the manufacturer's instructions, as already described (Carvalho et al., 2012). For the spontaneous sedimentation technique (Hoffman et al., 1934), one additional fecal sample was also collected in a sterile universal container without a preservative solution and stored at $4{ }^{\circ} \mathrm{C}$. The samples were analyzed at the Laboratory of Clinical Parasitology in Alfenas Federal University (Universidade Federal de Alfenas, UNIFAL-MG). 


\section{Questionnaire application}

A socio-epidemiological questionnaire was also sent to the parents or guardians, with questions relating to age, sex, parental level of education, housing conditions (paved street, water quality and backyard), hygiene habits, clinical symptoms, and the presence of pets.

\section{Statistical analysis}

Data were analyzed using the Epi Info ${ }^{\mathrm{TM}}$ software, version 7.2.1.0 (Centers for Disease Control and Prevention [CDC], Atlanta, GA, USA). Categorical variables were reported as frequencies, and the association between some risk factors and protozoan infection in the children was evaluated. The odds ratios (OR) and respective confidence intervals $(95 \%$ CIs) were calculated as a measurement of the strengths of associations. A value of $p<0.05$ was considered statistically significant.

\section{Ethical considerations}

This study was approved by the Research Ethics Committee of the UNIFAL-MG (Protocol no. 1.430.493; 098602/2015), and an informed consent document was sent to the children's parents or legal guardians to obtain their consent for participation of the child in the study.

\section{RESULTS}

A total of 621 children attending three DCCs, 188 from BJ, 135 from BV, and 298 from JB daycare centers, were invited to participate in this study; however, only $44.6 \%$ (277/621) provided fecal samples for detection of intestinal parasites through parasitological testing. The participation rates in the project showed great variation, according to the daycare center: $8.5 \%$ $(16 / 188)$ in BF, 31.8\% (43/135) in BV, and 73.1\% (218/298) in JB daycare.

Of the 277 children who participated by providing fecal samples, not all parents or guardians answered the questionnaire, and hence the socioepidemiological data could only be determined for $31.0 \%$ (86/277). From the children participating in the study, with ages varying from 0 to 70 months $(0$ to almost 6 years of age) and mean age of 35.9 months, $145(52.35 \%)$ were female and $132(47.65 \%)$ male. Parasitological examination revealed that at least one intestinal parasite or commensal species was detected in $29.6 \%$ $(82 / 277)$ of the children. Four children were infected with two species, and 78 children (95.1\%) presented mono-parasitism (Figure 2). 


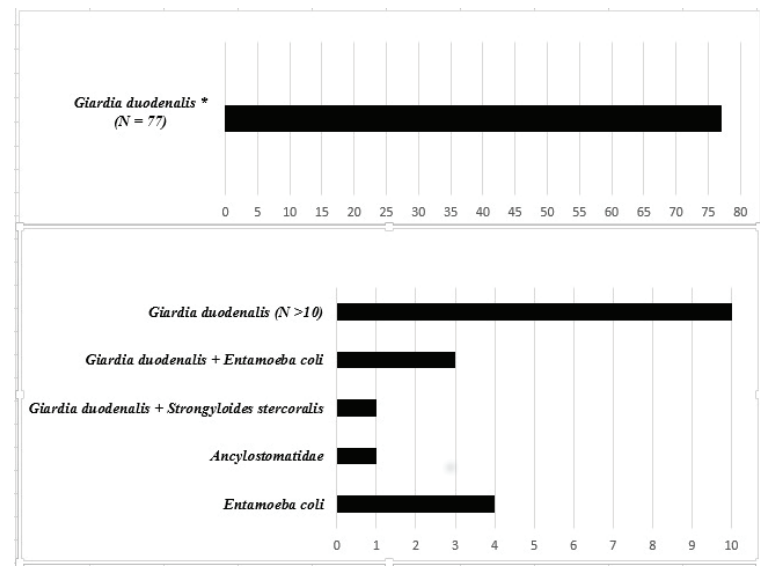

Figure 2. Distribution of single and double parasite infections among the 277 children of the three public daycare centers in the city of Alfenas, $\mathrm{MG}$

The most frequently detected parasite was Giardia duodenalis (syn. G. intestinalis, G. lamblia), with a positivity rate of $27.8 \%$ (77/277), with $28.3 \%$ (41/145) and $27.3 \%$ (36/132) positivity rates for girls and boys, respectively (Table 1), with no difference between the sexes (OR=1.05; 95\% CI: $0.62-1.78$; $\mathrm{p}=0.85)$. The positivity rates varied according to the daycare center. $\mathrm{BV}$, with a rate of $44.8 \%$ (21/43), presented the highest rate (Table 1), which was significantly higher than JB daycare center (OR=3.13; 95\% CI: 1.59-6.14; $\mathrm{p}=0.00065)$, but with no significant difference in relation to $\mathrm{BF}$ daycare center $(\mathrm{OR}=2.10 ; 95 \%$ CI: $0.62-7.07 ; \mathrm{p}=0.23$ ). Another intestinal protozoan detected was Entamoeba coli, with seven cases, five girls and two boys. These seven cases were detected in a single DCC (Table 1), and the positivity rate in this daycare center (BF) was $43.7 \%$ (7/16). Helminthiasis was diagnosed in two children, both attending the JB daycare center: hookworm eggs were detected in a 36-month-old boy, and Strongyloides stercoralis larvae were detected in a 48-month-old girl.

According to the results presented in Table 2, the 24-35 months old age group presented the highest positivity rate for $G$. duodenalis $(33.3 \%$; 21/63). However, no significant differences were obtained when compared to the $0-23$ months old age group, with a positivity rate of $22.5 \%(\mathrm{OR}=1.72$; $95 \%$ CI: 0.69 $4.27 ; \mathrm{p}=0.24)$, or to the $36-47$ months old age group, with a positivity rate of $23.4 \%(\mathrm{OR}=1.63 ; 95 \% \mathrm{CI}: 0.75-3.56 ; \mathrm{p}=0.22)$. With regard to $E$. coli, positive results were observed only in the higher age groups: five cases in the 48-59 months old group and two cases in the 60 or more months age group. When the children were classified in two age groups, one up to two years old, and the other over two years or age; all intestinal parasites considered, the positivity rate was higher in the older age group (30.8\%) than in the group up to two years old (22.5\%), but this difference had no statistical significance $(\mathrm{OR}=1.53 ; 95 \% \mathrm{CI}$ : $0.69-3.38) ; \mathrm{p}=0.29$ ). 
Table 1. Positivity rates for Giardia duodenalis and Entamoeba coli-positive children, according to sex, in the three studied daycare centers in Alfenas, MG.

\begin{tabular}{|c|c|c|c|c|c|c|c|c|c|c|c|c|}
\hline \multirow{3}{*}{$\begin{array}{l}\dot{\bar{\theta}} \\
\overline{0} \\
\stackrel{0}{0}\end{array}$} & \multicolumn{12}{|c|}{ DAYCARE CENTER } \\
\hline & \multicolumn{3}{|l|}{ BJ } & \multicolumn{3}{|c|}{$\mathrm{BV}$} & \multicolumn{3}{|l|}{ JB } & \multicolumn{3}{|c|}{ TOTAL } \\
\hline & $\mathrm{T}$ & GD & $\mathrm{EC}$ & $\mathrm{T}$ & GD & $\mathrm{EC}$ & $\mathrm{T}$ & GD & $\mathrm{EC}$ & $\mathrm{T}$ & GD & $\mathrm{EC}$ \\
\hline \multirow{2}{*}{$\mathrm{F}$} & 9 & 3 & 5 & 21 & 11 & 0 & 115 & 27 & 0 & 145 & 41 & 5 \\
\hline & & & & & & & & & & & $28.3 \%$ & \\
\hline \multirow{2}{*}{ M } & 7 & 2 & 2 & 22 & 10 & 0 & 103 & 24 & 0 & 132 & 36 & 2 \\
\hline & & & & & & & & & & & $27.3 \%$ & \\
\hline \multirow{2}{*}{$\mathrm{T}$} & 16 & 5 & 7 & 43 & 21 & 0 & 218 & 51 & 0 & 277 & 77 & 7 \\
\hline & & $31.3 \%$ & $43.7 \%$ & & $48.8 \%$ & & & $23.4 \%$ & & & $27.8 \%$ & $2.5 \%$ \\
\hline
\end{tabular}

$\mathrm{F}=$ Female $\mathrm{M}=$ Male $; \mathrm{T}=$ Total number of participating children; $\mathrm{GD}=$ number of Giardia duodenalis-positive children; EC = number of Entamoeba coli-positive children; $(\%)=$ positivity rates.

Table 2. Positivity rates for Giardia duodenalis and Entamoeba coli-positive children, according to age group (in months), for the three studied daycare centers in Alfenas, MG.

\begin{tabular}{|c|c|c|c|c|c|c|c|c|c|c|c|c|}
\hline \multirow{3}{*}{$\begin{array}{c}\text { Age } \\
\text { Group } \\
\text { (months) }\end{array}$} & \multicolumn{10}{|c|}{ DAYCARE CENTER } & & \\
\hline & $\mathrm{BF}$ & & & $\mathrm{BV}$ & & & $\mathrm{JB}$ & & & \multicolumn{3}{|c|}{ TOTAL } \\
\hline & $\mathrm{T}$ & GD & $\mathrm{EC}$ & $\mathrm{T}$ & GD & $\mathrm{EC}$ & $\mathrm{T}$ & GD & $\mathrm{EC}$ & $\mathrm{T}$ & GD & EC \\
\hline \multirow{2}{*}{$0-23$} & 0 & 0 & 0 & 7 & 3 & 0 & 33 & 6 & 0 & 40 & 9 & 0 \\
\hline & & & & & & & & & & & $22.5 \%$ & \\
\hline \multirow{2}{*}{$24-35$} & 1 & 0 & 0 & 19 & 9 & 0 & 43 & 12 & 0 & 63 & 21 & 0 \\
\hline & & & & & & & & & & & $33.3 \%$ & \\
\hline \multirow{2}{*}{$36-47$} & 1 & 0 & 0 & 12 & 6 & 0 & 51 & 9 & 0 & 64 & 15 & 0 \\
\hline & & & & & & & & & & & $23.4 \%$ & \\
\hline \multirow{2}{*}{$48-59$} & 6 & 2 & 5 & 5 & 3 & 0 & 80 & 21 & 0 & 91 & 26 & 5 \\
\hline & & & & & & & & & & & $28.6 \%$ & \\
\hline \multirow{2}{*}{$\geq 60$} & 8 & 3 & 2 & 0 & 0 & 0 & 11 & 3 & 0 & 19 & 6 & 2 \\
\hline & & & & & & & & & & & $31.6 \%$ & \\
\hline \multirow[b]{2}{*}{ Total } & 16 & 5 & 7 & 43 & 21 & 0 & 218 & 51 & 0 & 277 & 77 & 7 \\
\hline & & $31.3 \%$ & $43.7 \%$ & & $48.8 \%$ & & & $23.4 \%$ & & & $27.8 \%$ & \\
\hline
\end{tabular}

$\mathrm{T}=$ Total number of participating children; $\mathrm{GD}=$ number of Giardia duodenalis positive children; EC = number of Entamoeba coli positive children; $(\%)=$ positivity rates. 
Table 3. Analysis of some risk factors associated with Giardia duodenalis infection among children of three daycare centers in Alfenas, MG.

\begin{tabular}{|c|c|c|c|c|c|c|}
\hline \multicolumn{2}{|c|}{$\begin{array}{l}\text { Risk factors Positive } \\
\text { (Positivity rate) }\end{array}$} & \multicolumn{2}{|c|}{$\begin{array}{c}\text { Parasitological exam } \\
\text { result } \\
\text { Negative }\end{array}$} & $\begin{array}{l}\text { Odds } \\
\text { Ratio* }\end{array}$ & $\begin{array}{c}95 \% \\
\text { Confidence } \\
\text { Interval }\end{array}$ & p-value \\
\hline \multirow{2}{*}{$\begin{array}{l}\text { Father's } \\
\text { schooling }\end{array}$} & $\begin{array}{l}\text { Up to } 8 \\
\text { years }\end{array}$ & $11(32.35 \%)$ & 23 & \multirow{2}{*}{1.14} & \multirow{2}{*}{$0.43-3.00$} & \multirow[t]{2}{*}{0.79} \\
\hline & $\begin{array}{c}\text { More than } \\
8 \text { years }\end{array}$ & $13(29.55 \%)$ & 31 & & & \\
\hline \multirow{2}{*}{$\begin{array}{l}\text { Mother's } \\
\text { schooling }\end{array}$} & $\begin{array}{l}\text { Up to } 8 \\
\text { years }\end{array}$ & $10(35.7 \%)$ & 18 & \multirow{2}{*}{1.33} & \multirow{2}{*}{$0.50-3.55$} & \multirow{2}{*}{0.57} \\
\hline & $\begin{array}{c}\text { More than } \\
8 \text { years }\end{array}$ & $15(29.4 \%)$ & 36 & & & \\
\hline \multirow[t]{2}{*}{ Family size } & $\begin{array}{l}\text { Up to } 4 \\
\text { people }\end{array}$ & $18(36.0 \%)$ & 32 & \multirow[t]{2}{*}{1.56} & \multirow[t]{2}{*}{$0.60-4.07$} & \multirow[t]{2}{*}{0.36} \\
\hline & $\begin{array}{l}\text { More than } \\
4 \text { people }\end{array}$ & $9(26.5 \%)$ & 25 & & & \\
\hline \multirow{2}{*}{$\begin{array}{l}\text { Household on } \\
\text { paved street }\end{array}$} & Yes & $25(32.5 \%)$ & 52 & \multirow[t]{2}{*}{1.04} & \multirow[t]{2}{*}{$0.24-4.50$} & \multirow[t]{2}{*}{0.96} \\
\hline & No & $3(33.3 \%)$ & 6 & & & \\
\hline \multirow[t]{2}{*}{$\begin{array}{l}\text { Land in the } \\
\text { backyard }\end{array}$} & Yes & $9(33.3 \%)$ & 18 & \multirow[t]{2}{*}{1.05} & \multirow[t]{2}{*}{$0.40-2.77$} & \multirow[t]{2}{*}{0.92} \\
\hline & No & $19(32.8 \%)$ & 40 & & & \\
\hline \multirow{2}{*}{$\begin{array}{c}\text { Animal } \\
\text { presence in the } \\
\text { house }\end{array}$} & Yes & $12(24.0 \%)$ & 38 & \multirow[t]{2}{*}{2.53} & \multirow[t]{2}{*}{$1.01-6.38$} & \multirow[t]{2}{*}{0.046} \\
\hline & No & $16(44.4 \%)$ & 20 & & & \\
\hline \multirow{2}{*}{$\begin{array}{c}\text { Clinical signs } \\
\text { present }\end{array}$} & Yes & $6(33.3 \%)$ & 13 & \multirow{2}{*}{1.03} & \multirow{2}{*}{$0.33-3.17$} & \multirow{2}{*}{0.96} \\
\hline & No & $17(30.9 \%)$ & 38 & & & \\
\hline
\end{tabular}

*OR values calculated comparing the two categories in each risk factor (Up to x More than 8 years; Up to $\mathrm{x}$ More than 4 people; Yes $\mathrm{x}$ No) 
Based on 86 socio-epidemiological questionnaires, the data revealed that $89.5 \%$ of the children (77/86) lived in houses on paved streets. Concerning household sanitary conditions, almost all of the houses $(97.6 \%$; 80/82) had access to the public water supply system. With regard to the fathers' and mothers' levels of education, 56.4\% (44/78) and 64.6\% (51/79), respectively, had had more than eight years of formal schooling. As for the size of the family, 59.5\% (50/84) of the children belonged to families with up to four members. More than half of the households $(58.1 \%$; 50/86) kept a pet, mainly dogs $(68.0 \%$; 34/50). Regarding the clinical manifestations, such as diarrhea and abdominal pain, most of the children $(74.3 \%$; 55/74) had presented no symptoms from one month before until the time of the survey (Table 3).

The distribution of protozoan infections among the children according to some risk factors, with the OR, respective $95 \% \mathrm{CIs}$, and $\mathrm{p}$ values, is shown in Table 3. Although a statistical significance has not been verified, some factors, such as the mother's level of education, family size, and the presence of animals in the home, have been shown to be associated with protozoan infection.

\section{DISCUSSION}

Intestinal parasitic infections persist as neglected diseases that can lead to adverse consequences, particularly for preschool age children living in low socio-economic areas (Fletcher et al., 2012; Hotez, 2014). Children are an important high-risk group for helminth and protozoa infections. Childhood enteric parasite diseases are of great relevance for frequent association with chronic diarrhea and malnutrition, factors that can cause physical and cognitive deficiencies and even death (Berkman et al., 2002; Pedraza et al., 2014).

Preschoolers constitute a part of the population that is biologically vulnerable to disease, mainly due to their immature and inexperienced immune systems (Pedraza et al., 2014). The decrease in maternal antibody levels, with the consequent drop in passive immunity, at 6 to 12 months of age may also contribute to an increased risk of acquiring disease, especially for those 1 to 2 years old (Lee \& Greig, 2008). Studies have shown that children attending DCCs tend to be less healthy than those cared for exclusively at home. Gastrointestinal diseases are a common occurrence in DCCs and can spread easily by keeping together, in a confined space, numerous children from different origins (Lee \& Greig, 2008; Pedraza et al., 2014). In DCCs which are collective environments, children are likely to acquire intestinal parasites due to the common aspects observed in these establishments: Easy interpersonal contact (child-child, child-employee-child), inadequate staff training, and some characteristics usually inherent to children attending DCCs such as precarious hygiene habits, oral phase exploration, and frequent contact with soil (Gonçalves et al., 2011; Mateo et al., 2014. DCCs are necessary in view 
of the socio-economic transformations that have occurred in recent decades, namely greater involvement of women in the labor force. With more mothers working outside the home, a growing demand for child care institutions has arisen (Lee \& Greig, 2008; Pedraza et al., 2014).

This study evidenced that parasitic infections were common among children attending DCCs in Alfenas, MG, revealing that at least one intestinal parasite or commensal species was detected in $29.6 \%$ of them. This is in accordance with studies carried out at DCCs in different Brazilian cities, which have shown a wide variation in the prevalence of intestinal parasitic diseases, ranging from $24.6 \%$ to $29.3 \%$ (Gonçalves et al., 2011; Nobre et al., 2013). Some studies have revealed higher prevalence data, reaching 55\% in Niterói, RJ (Uchôa et al., 2001), and 49\% in São José do Rio Preto, SP(Castro et al., 2015); and values close to $40 \%$, such as $40.6 \%$ in Botucatu, SP(Oliveira-Arbex et al., 2016), 39.6\% in Blumenau, SC (Tashima et al., 2009), 38.6\% in President Bernardes, SP(Andrade et al., 2008), and 36.6\% in Vale do Aço, MG (Magalhães et al., 2013).

In this study, the most frequent parasite was G. duodenalis, corroborating data on children attending DCCs in different Brazilian cities, as reported in other investigations (Uchôa et al., 2001; Menezes et al., 2008; Gonçalves et al., 2011; Magalhães et al., 2013). The study conducted in a DCC in Belo Horizonte, MG (Nobre et al., 2013), was the only one where the most prevalent protozoan was the commensal Entamoeba coli at $14 \%$, which is higher than the $9.5 \%$ positivity detected for G. duodenalis. In this study, carried out in Alfenas, MG, G. duodenalis was detected in $27.8 \%$ of the DCC children, an expected positivity rate. The prevalence of this parasite is known to be higher in children than in adults, especially in DCCs, where some previously discussed intrinsic characteristics in children attending DCCs may enable closer contact with the infecting forms (Gonçalves et al., 2011; Mateo et al., 2014; Pedraza et al., 2014).

On the other hand, the detected prevalence may be considered high, taking into account that this study was carried out in an urban area of Alfenas city, with $90 \%$ of the studied children living in houses on paved streets, and almost all with access to the public water supply system. G. duodenalis is the most frequent intestinal protozoa nowadays, whether in technologically advanced societies or in developing countries (Fletcher et al., 2012; Hotez, 2014); around the world. The protozoan $G$. duodenalis is, along with Cryptosporidium, one of the most common causes of waterborne disease outbreaks associated with drinking water or recreational water, as a result of inappropriate water treatment or cross-contamination of potable water with sewage water (Baldursson \& Karanis, 2011; Fletcher et al., 2012).

Even if diagnostic tools were different, as summarized by Osman et al. (2016), recent studies on asymptomatic children worldwide have reported a $1 \%$ giardiasis prevalence in the USA and Italy, $7 \%$ in Portugal and Pakistan, $15 \%$ in 
Syria, 18\% in Yemen, and 32\% in Russia. Regarding children attending DCCs or kindergartens, studies have showed giardiasis prevalence of $1.3 \%$ in the United Kingdom(Davies et al., 2009), 1.5\% in Germany (Sagebiel et al., 2009), 4.2\% in The Netherlands (Enserink et al., 2014), 15.6\% in Spain (Mateo et al., 2014), 28.5\% in the Lebanon (Osman et al., 2016), and 54.8\% in Cuba(Canete et al., 2012). In Brazil, according to some studies, reported between 2010 and 2016, the prevalence data for giardiasis, among the DCC children, varied from 13\% (Lander et al. 2012) to 44\% (Castro et al., 2015); and in population surveys, including children and adults, ranged from $0.9 \%$ (Casavechia et al., 2016) to $18.2 \%$ (Sanches et al., 2013). The different prevalence rates noted in various Brazilian regions, as well as worldwide, may be associated with the number of sample collections and the methodology used. On the other hand, these might also be associated with the large diversity in geographic, social, economic, and climactic characteristics, reported as significant factors in the occurrence and distribution of different enteric pathogens (Fletcher et al., 2012; Castro et al., 2015).

Although no statistical significance was verified in the children from the Alfenas DCCs, the highest frequency for G. duodenalis (33.3\%) was detected for the 24-35 months age group (2 to 3 years old). According to other studies, the highest frequency for this protozoan was associated with the 1-2 years of age range, followed by the over 3 year-old population, which is probably related to the high rate of fecal-oral transmission of this pathogen (Harhay et al., 2010; Castro et al., 2015). In this study, considering all the parasites, $22.5 \%$ of the children under 2 years of age were positive, whereas $30.8 \%$ of those aged 24 months or more were positive for at least one parasite. This finding is in accordance with the results observed by Mulatu et al. (2015). These authors detected a positivity rate of $51.1 \%$ for children aged two and over, which was significantly higher than the under 24 months age group, with a positive rate of $16.2 \%$.

This study identified a low frequency of Entamoeba coli (2.5\%) when considering all the children of the three DCCs studied, suggesting that this amoeba may not be endemic in the region. However, in the BF daycare center, this commensal parasite was detected at a high frequency $(43.7 \%)$, and this might be indicative that the children in this DCC are at risk of being contaminated by other enteric pathogens (Castro et al., 2015).

According to Da Silva et al. (2016), in a study on enteroparasite contamination of peridomiciliary soil, the parasitic forms most commonly found in the soil were Entamoeba spp. cysts, detected in $5.2 \%$ of the examined soil samples, suggesting that this finding might be used as a possible soil contamination marker. The high prevalence of a commensal parasite may indicate precarious sanitary conditions or environmental contamination (Menezes et al., 2008), therefore the situation in this specific DCC must be 
further investigated, stressing the importance of sanitary education focusing on hygiene measures.

In this study, only two cases of helminth infection were identified, both in the same DCC: a 36-month-old boy with hookworm and a 48-month-old girl with Strongyloides stercoralis associated with G. duodenalis. This low frequency of helminthes is in accordance with data observed in other DCCs, especially in the south and southeast regions of Brazil (Andrade et al., 2008; Castro et al., 2015; Oliveira et al., 2016). Higher rates of helminth infections have been reported in studies carried out at DCCs in eastern and northeastern Brazil (Gurgel et al., 2005; Lander et al., 2012; Nobre et al., 2013). There is a historical trend toward the reduction of these parasites in urban areas, especially in the southeast region of Brazil, possibly related to issues such as improvement in sanitation and hygiene habits (Castro et al. 2015).

Most of the children in this study (74.3\%) did not present clinical manifestations, such as diarrhea and abdominal pain. This finding is repeated in data obtained in similar studies in DCCs in different Brazilian cities (Tashima et al., 2009; Castro et al., 2015) and in other countries (Davies et al., 2009; Enserink et al., 2014). The finding that $3 / 4$ of the Giardia-infected children did not present clinical manifestations is cause for serious public health concern, since asymptomatic carriers can contribute to the spread of the infection to healthy individuals (Berkman et al., 2002; Mateo et al., 2014). Therefore, it is important to detect asymptomatic giardiasis to minimize the possibility of child-to-child or child-to-adult transmission, either at the DCC or at home.

The present study evidences that intestinal parasitic infections continue to be a health issue in the DCCs in Alfenas, MG, indicating the importance of periodic surveys in these settings. Therefore, preventive measures must be considered and implemented, including improvement of sanitary conditions, periodic treatment, and educational activities to disseminate information on the prophylaxis of intestinal parasites and good hygiene practices.

\section{ACKNOWLEDGMENTS}

To the Secretary of Education of Alfenas, Minas Gerais; to the Dean of Extension of the Federal University of Alfenas, Minas Gerais; To undergraduate students who participated in the execution of the project. Financial support: Proext MEC/SESU 2014.

\section{REFERENCES}

1. Andrade F, Rode G, Silva Filho HH, Greinert-Goulart JA. Parasitoses intestinais em um centro de educação infantil público do município de Blumenau, SC, Brasil, com ênfase em Cryptosporidium spp e outros protozoários. Rev Patol Trop 37: 332-340 2008.

2. Baldursson S, Karanis P. Waterborne transmission of protozoan parasites: Review of worldwide outbreaks - An update 2004-2010. Water Res 45: 6603 -6614, 2011. 
3. Berkman DS, Lescano AG, Gilman RH, Lopez SL, Black MM. Effects of stunting, diarrhoeal disease, and parasitic infection during infancy on cognition in late childhood: a follow-up study. Lancet. 359: 564-571, 2002.

4. Canete R, Diaz MM, Avalos Garcia R, Laud Martinez PM, Manuel Ponce F. Intestinal parasites in children from a day care centre in Matanzas City, Cuba. PLoS One. 7: e51394, 2012.

5. Carvalho GLX, Moreira LE, Pena JL, Marinho CC, Bahia MT, Machado-Coelho GLL. A comparative study of the TF-Test ${ }^{\circledR}$, Kato-Katz, Hoffman-Pons-Janer, Willis and BaermannMoraes coprologic methods for the detection of human parasitosis. Mem Inst Oswaldo Cruz 107: 80-84, 2012.

6. Casavechia, MTG, Lonardoni MVC, Venazzi EAS, Campanerut-Sá PAZ, Benalia HRC, Mattiello MF, Menechin PVL. Prevalence and predictors associated with intestinal infections by protozoa and helminths in southern Brazil. Parasitol Res 115: 2321-2329, 2016.

7. Castro ED, Germini MC, Mascarenhas JD, Gabbay YB, Lima IC, Lobo P S, Fraga VD, Conceição LM, Machado RL, Rossit AR. Enteropathogens detected in a daycare center, Southeastern Brazil: bacteria, virus, and parasite research. Rev Inst Med Trop São Paulo 57: 27-32, 2015.

8. Da Silva JB, Piva C, Falavigna-Guilherme AL, Rossoni DF, De Ornelas Toledo MJ. Spatial distribution and enteroparasite contamination in peridomiciliar soil and water in the Apucaraninha Indigenous Land, southern Brazil. Environ Monit Assess 188: 217, 2016.

9. Davies AP, Campbell B, Evans MR, Bone A, Roche A, Chalmers RM. Asymptomatic carriage of protozoan parasites in children in day care centers in the United Kingdom. Pediatr Infect Dis J. 28: 838-840, 2009.

10. Enserink R, Scholts R, Bruijning-Verhagen P, Duizer E, Vennema H, Boer, R Kortbeek T, Roelfsema J, Smit H, Kooistra-Smid M, Pelt WV. High detection rates of enteropathogens in symptomatic children attending day care. PLoS One 9: e89496, 2014.

11. Fletcher SM, Stark D, Harkness J, Elli J. Enteric Protozoa in the Developed World: a Public Health Perspective. Clin Microbiol Rev 25: 420-449, 2012.

12. Gonçalves AL, Belizário TL, Pimentel JB, Penatti MP, Pedroso RS. Prevalence of intestinal parasites in preschool children in the region of Uberlândia, State of Minas Gerais, Brazil. Rev Soc Bras Med Trop 44: 191-193, 2011.

13. Gurgel RQ, Cardoso G de S, Silva AM, Santos LN, Oliveira RC. Creche: ambiente expositor ou protetor nas infestações por parasitas intestinais em Aracaju, SE. Rev Soc Bras Med Trop 38: 267-269, 2005.

14. Harhay MO, Horton J, Olliaro PL. Epidemiology and control of human gastrointestinal parasites in children. Expert Rev Anti Infect Ther 8: 219-234, 2010.

15. Hoffman WA, Pons JA, Janer JL. Sedimentation concentration method in Schistosomiasis mansoni. Puerto Rico. J Public Health 9: 283-298, 1934.

16. Hotez PJ. Neglected Parasitic Infections and Poverty in the United States. PLoS Negl Trop Dis 8: e3012, 2014.

17. IBGE (Instituto Brasileiro de Geografia e Estatística). Cidades@. Minas Gerais, Alfenas. Disponível em: http://cidades.ibge.gov.br/xtras/perfil.php?codmun=310160. Acesso em 10/06/2016.

18. Lander RL, Lander AG, Houghton L, Williams SM, Costa-Ribeiro H, Barreto DL, Mattos AP, Gibson RS. Factors influencing growth and intestinal parasitic infections in preschoolers attending philanthropic daycare centers in Salvador, Northeast Region of Brazil. Cad Saude Publica 28: 2177-2188, 2012.

19. Lee MB, Greig JD. A review of enteric outbreaks in child care centers: effective infection control recommendations. J Environ Health 71: 24-32, 2008. 
20. Magalhães RF, Amaroa PF, Soaresa EB, Lopesa LA, Mafrab RSP, Albertibc LR. Ocorrência de Enteroparasitoses em Crianças de Creches na Região do Vale do Aço - MG, Brasil. UNOPAR. Cient Ciênc Biol Saúde 15: 187-191, 2013.

21. Mulatu G, Zeynudin A, Zemene E, Debalke S, Beyene G. Intestinal parasitic infections among children under five years of age presenting with diarrheal diseases to two public health facilities in Hawassa, South Ethiopia. Infect Dis Poverty 4: 49-56, 2015.

22. Mateo M, Mateo M, Montoya A, Bailo B, Saugar JM, Aguilera M, Fuentes I, Carmena D. Detection and molecular characterization of Giardia duodenalis in children attending day care centers in Majadahonda, Madrid, Central Spain. Medicine (Baltimore) 93: e75, 2014.

23. Menezes AL, Lima, VMP, Freitas MTS, Rocha MO, Silva EF, Dolabella SS. Prevalence of intestinal parasites in children from public daycare centers in the city of Belo Horizonte, Minas Gerais, Brazil. Rev Inst Med Trop São Paulo 50: 57-59, 2008.

24. Nobre LN, Silva RV, Macedo MS, Teixeira RA, Lamounier JA, Franceschini SC. Risk factors for intestinal parasitic infections in preschoolers in a low socio-economic area, Diamantina, Brazil. Pathog Glob Health 107: 103-106, 2013.

25. Oliveira-Arbex AP, David EB, Oliveira-Sequeira TC, Bittencourt GN, Guimarães S. Genotyping of Giardia duodenalis isolates in asymptomatic children attending daycare centre: evidence of high risk for anthroponotic transmission. Epidemiol Infect 144: 1418-1428, 2016.

26. Osman M, El Safadi D, Cian A, Benamrouz S, Nourrisson C, Poirier P, Pereira B, Razakandrainibe R, Pinon A, Lambert C, Wawrzyniak I, Dabboussi F, Delbac F, Favennec L, Hamze M, Viscogliosi E, Certad G. Prevalence and Risk Factors for Intestinal Protozoan Infections with Cryptosporidium, Giardia, Blastocystis and Dientamoeba among schoolchildren in Tripoli, Lebanon. PLoS Negl Trop Dis 10: e0004496, 2016.

27. Pedraza DF, Queiroz D, Sales MC. Doenças infecciosas entre crianças brasileiras em idade pré-escolar atendidas em creches. Cien Saude Colet 19: 511-528, 2014.

28. Sagebiel D, Weitzel T, Stark K, Leitmeyer K. Giardiasis in kindergartens: prevalence study in Berlin, Germany, 2006. Parasitol Res 105: 681-687, 2009.

29. Sanches FG, Machado ECS, Soares RP, Norberg NA, Madeira de Oliveira JT, Serra-Freire NM. Parasitismo intestinal na comunidade rural de Marancó, Município de Santa Brígida, Estado da Bahia, Brasil. Rev Saúde Física \& Mental-UNIABEU 3: 39-49, 2013.

30. Tashima NT, Simões MJ, Leite CQ, Fluminhan A, Nogueira MA, Malaspina AC. Classic and molecular study of Giardia duodenalis in children from a daycare center in the region of Presidente Prudente, São Paulo, Brazil. Rev Inst Med Trop Sao Paulo 51: 19-24, 2009.

31. Uchôa CMA, Lobo AGB, Bastos OMP, Matos AD. Parasitoses intestinais: prevalência em creches comunitárias da cidade de Niterói, Rio de Janeiro, Brasil. Rev Inst Adolfo Lutz 60: 97-101, 2001. 